\title{
REGIONALNE UNIWERSUM SYMBOLICZNE \\ WYSP ALANDZKICH
}

\author{
GENEZA
}

W lutym 1918 roku delegacja mieszkańców Wysp Alandzkich przybyła do Sztokholmu, by złożyć na ręce króla Gustawa $V$ petycję o ponowne przyłączenie archipelagu do Szwecji1. Ich działanie było reakcją na wydarzenia rewolucyjne w Rosji i na ogtoszoną 6 grudnia 1917 roku deklarację niepodległości Finlandii, ale jego genezy szukać należy ponad sto lat wcześniej, gdy wojska cara Aleksandra I zajęły Finlandię i, wykorzystując do przeprawy lód skuwający Zatokę Botnicką, dwukrotnie - najpierw przejściowo w roku 1808, a rok później już na stałe zajęły wyspy². Wypełnity w ten sposób decyzje strategiczne przyjęte przez Napoleona i Aleksandra w Tylży i w Erfurcie, a przewidujące zajęcie przez Rosję fińskiej części Szwecji. Zdobycze militarne potwierdzone zostały odpowiednimi aktami prawnymi. Car do innych swych godności dodał tytuł Wielkiego Księcia Finlandii, a w marcu 1809 roku odbyło się Zgromadzenie Krajowe w Parvoo (szw. Borgå), na które przybyli przedstawiciele stanów i regionów Finlandii i na którym wśród delegatów stanu duchownego znalazł się jeden przedstawiciel Wysp Alandzkich. Przyniosto ono z jednej strony uznanie Finów za odrębny naród i utworzenie dla niego odrębnego państwa, z drugiej zaakceptowanie Wielkiego Księcia jako jego władcy ${ }^{3}$. W efekcie działań

Dr Grzegorz BONUSIAK jest adiunktem w Zakładzie Studiów Europejskich na Wydziale Prawa i Administracji Uniwersytetu Rzeszowskiego. gbon@interia.pl

1 O. Jussila, S. Hentilä, J. Nevakivi, Historia polityczna Finlandii 1809-1999, tłum. B. Kojro, Kraków 2001 s. 117. Spośród około 12,5 tys. uprawnionych do głosowania obecnych było około 8 tys., a 7135 osób podpisało petycje "Do króla i ludu szwedzkiego". Por.: M. Suksi, The Aland Islands in Finland, [w:] Local selfgovernment, territorial integrity and protection of minorities, Council of Europe, Strasbourg 1996, s. $23-24$.

2 E. Kosiarz, Wojny na Baltyku X-XIX W., Gdańsk 1978, s. 354 i 362.

3 O. Jussila, S. Hentilä, J. Nevakivi, Historia polityczna Finlandii..., s. 16-18. 
militarnych i decyzji politycznych, częścią księstwa miał się stać również leżący pomiędzy wybrzeżem Szwecji a Finlandii archipelag Wysp Alandzkich, co potwierdzone zostało traktatem pokojowym podpisanym 17 września 1809 roku w Haminie (szw. Fredrikshamn). Zgodnie z postanowieniami zawartymi w art. 4 tego aktu nowy władca Szwecji, Karol XIII, w imieniu swoim i królestwa zrzekał się na rzecz Aleksandra i Rosji szwedzkiej części Finlandii wraz z Wyspami Alandzkimi. Natomiast art. 5 stanowił, że granica pomiędzy państwami przebiegać miała Morzem Alandzkim i Zatoką Botnicką, w równej z obu stron odległości od brzegów ${ }^{4}$. W ten sposób na kolejne sto lat Wyspy stały się częścią imperium, a jego mieszkańcy poddanymi cara, dzieląc doświadczenia zmieniającej się polityki narodowościowej Rosji nie tylko z innymi mieszkańcami Finlandii, ale również między innymi z Polakami. Jak się później okazało XIX wiek był przede wszystkim czasem umacniania tożsamości narodowej Finów. Na Wyspach o okresie przynależności do imperium rosyjskiego przypomina nazwa stolicy regionu Mariehamn (fin. Mariehamina), która założona została w 1861 roku i nazwana tak na cześć Marii, żony cara Aleksandra II.

Postulaty powrotu Wysp Alandzkich do macierzy zostały wyartykułowane oficjalnie w sierpniu 1917 roku na spotkaniu mieszkańców w szkole w osadzie Jomala. Wydaje się, że nałożyły się na siebie dwie tendencje. Z jednej strony w obliczu wielkich wydarzeń historycznych odżyło poczucie przynależności do Szwecji i narodu szwedzkiego oraz chęć wykorzystania sytuacji geopolitycznej dla cofnięcia niechcianych historycznych rozstrzygnięć. Z drugiej - wyspiarze poszukiwali ochrony przed wojenną zawieruchą, a zachowująca neutralność Szwecja wydawała się odpowiednim adresatem takich oczekiwań. Trwające działania wojenne, a zwłaszcza obecność oddziałów wojsk rosyjskich skutecznie blokowały wszelkie radykalne gesty. Dopiero rewolucja listopadowa i proklamacja niepodległości Finlandii nadały rozpędu ujawniającym się dążeniom. Gdy w styczniu 1918 roku w Finlandii wybuchła wojna domowa pomiędzy zwolennikami rewolucji, dysponującymi robotniczymi oddziałami Gwardii Czerwonej i korzystającymi ze wsparcia bolszewików, a dowodzonymi przez Carla Mannerheima oddziałami białych, Wyspy opowiedziały się po stronie konserwatystów. Pomimo zajęcia całego rejonu Turku przez czerwonych, archipelag pozostał poza ich strefą wpływów. Niewielkie starcia miały miejsce jedynie w pobliżu osady Godby ${ }^{5}$. Jednak brak większych walk i zdecydowane opowiedzenie się po stronie białych wynikały przede wszystkim z opóźnienia gospodarczego Wysp i niewielkiego ich nasycenia przemystem, a zatem z braku robotników będących dostarczycielem poparcia i siły ludzkiej dla wojsk czerwonych. Oficjalnie, aby nie dopuścić do eskalacji przemocy i chronić szwedzkojęzyczną ludność Wysp, 15 lutego 1918 roku na Morzu Alandzkim pojawiły się okręty szwedzkie i rozpoczęły wysadzanie oddziału desantowego w sile 600 żołnierzy. Pod groźbą użycia siły, ale i dzięki umiejętnościom negocjacyjnym szwedzkiego dowódcy wiceadmirała Ehrensvärda w wielostronnych negocjacjach przyjęto decyzję o wycofaniu z Wysp wszystkich wojsk. 23 lutego ewakuację rozpoczęły oddziały armii czerwonej i czerwoni gwardziści, pozostawiając archipelag w rękach szwedzkich, których wojska, łamiąc wcześniejsze ustalenia, nie zamierzały się wycofać ${ }^{6}$.

Szwedzka zwierzchność nad archipelagiem, choć entuzjastycznie witana przez wyspiarzy, potrwała bardzo krótko. 6 marca do wybrzeży Wysp Alandzkich dotarł zespół okrętów niemieckich, wiozący na swych pokładach batalion desantowy w sile tysiąca żołnierzy. Po krótkich negocjacjach, realizując wcześniejsze ustalenia międzyrządowe, siły szwedzkie .......

4 Por. tekst traktatu w języku rosyjskim w: W.W. Dubin, W.W. Roginskij, S. Junson (red.), Rossija i Szwecija. Dokumienty i materiały 1809-1818, Moskva 1985, s. 5-12.

5 Åland in Brief, Mariehamn 2008, s. 22.

6 E. Kosiarz, Pierwsza wojna światowa na Battyku, Gdańsk 1979, s. 361. 
wycofały się z archipelagu, a kontrolę militarną przejęli lądujący Niemcy. W ten sposób Wyspy nie tylko stały się niemiecką bazą wojenną, ale także ważnym ośrodkiem białych sił fińskich. Trafiły tu złożone z Finów oddziały jegrów, wcześniej szkolone w Niemczech, z których sformowano dowodzony przez niemieckich oficerów korpus szkierowy?. Przybywali uciekający przed siłami gwardyjskimi biali, głównie z zajętego przez czerwonych rejonu Turku. Także do portów na Wyspach kierowały się statki obsadzone przez fińskich kontrrewolucjonistów uciekające z obszarów zajętych przez czerwonych ${ }^{8}$.

Kiedy w maju oddziały Mannerheima uczestniczyły w wielkiej paradzie zwycięstwa mającej uczcić wycofanie z Finlandii ostatnich oddziałów czerwonych, separatyści alandzcy szykowali się do walki o realizację swych postulatów powrotu do Szwecji. Pierwszym krokiem było powołanie rady mającej reprezentować ich interesy, która wzięła na siebie ciężar organizowania protestów i poszukiwania poparcia na forum międzynarodowym. 11 listopada 1918 roku delegacje wyspiarzy złożyły petycje w ambasadach Stanów Zjednoczonych, Wielkiej Brytanii, Francji i Włoch, w których, opierając się na słowach W. Wilsona o prawie narodów do samostanowienia, domagały się międzynarodowego poparcia dla pomysłu przeprowadzenia na wyspach plebiscytu mającego rozstrzygnąć sprawę ich przynależności państwowej ${ }^{9}$. Koncepcja znalazła poparcie dyplomacji szwedzkiej i francuskiej i trafiła pod obrady delegatów zebranych na konferencji w Wersalu. Także wyspiarze wysłali na nią swoją trzyosobową delegację, by ta poszukiwała przychylności opinii międzynarodowej dla ich koncepcji. Jednak uczestnicy konferencji uznali, że rozstrzygnięcie konfliktu leży poza ich kompetencjami, a na wniosek dyplomacji brytyjskiej sprawa trafiła pod rozwage Ligi Narodów, której członkami były obydwa zainteresowane państwa. Wprawdzie Finowie podnosili, że sprawa nie podlega jurysdykcji LN, gdyż jest wewnętrznym problemem Finlandii, jednak specjalna komisja prawników oddaliła te zastrzeżenia ${ }^{10}$.

Szykując się do sporu na forum międzynarodowym, parlament Finlandii w maju 1920 roku przyjął zapobiegawczo ustawę o autonomii Wysp Alandzkich. Przewidywała ona szeroki samorząd regionalny, posiadanie własnego parlamentu i rządu, prawo do używania języka szwedzkiego, a także podtrzymywała pochodzącą jeszcze z czasów wojny krymskiej zasadę demilitaryzacji archipelagu, rozszerzając ją o zwolnienie mieszkańców z obowiązkowej służby wojskowej. Poszukując poparcia dla tej koncepcji, na Wyspy przybył ówczesny fiński premier R. Erich. Jednak istniejący od czasu interwencji szwedzkiej i niemieckiej, nieuznawany przez Finów parlament wyspiarzy, zareagował negatywnie na inicjatywę fińską, raz jeszcze potwierdzając dążenia mieszkańców do połączenia ze Szwecją ${ }^{11}$. Doprowadziło to do wzrostu napięcia i w konsekwencji do aresztowania dwóch najbardziej aktywnych regionalnych przywódców, Juliusa Sundbloma i Carla Björkmana, pod zarzutem zdrady sta$n u^{12}$. Stali się oni dla regionalnej społeczności bohaterami walki o prawo do samostanowienia i ponownego połączenia ze Szwecją. Rok później, w geście dobrej woli strony fińskiej, obaj zostali oswobodzeni i oczyszczeni z zarzutów, a po unormowaniu sytuacji politycznej zajęli eksponowane stanowiska w nowych władzach regionalnych.

7 Czyli piechoty morskiej szkolonej specjalnie do walk na bałtyckich wybrzeżach szkierowych, pełnych małych skalistych wysepek powstałych po zalaniu przez morze obszarów, z których ustąpił lodowiec. Cechą charakterystyczną szkierów są płytkie wody i zmienne wiatry, utrudniające używanie żagla i uniemożliwiające wprowadzanie okrętów o większym zanurzeniu.

8 Tamże, s. 362-364.

9 S. Sierpowski, Liga Narodów w latach 1919-1926, Wrocław-Warszawa-Kraków 2005, s. 80.

10 W jej skład wchodziło trzech prawników: F. Larnaude z Francji, A. Straycken z Holandii i M. Huber ze Szwajcarii. Tamże, s. 81.

11 M. Sobczyński, Rola i miejsce Wysp Alandzkich w Unii Europejskiej, [w:] R. Żelichowski (red.), Małe państwa Europy zachodniej i terytoria o statusie specjalnym. Ich rola i miejsce w Unii Europejskiej, Warszawa 2008, s. 132.

12 O. Jussila, S. Hentilä, J. Nevakivi, Historia polityczna Finlandii..., s. 151. 
Datowany na 16 kwietnia 1921 roku raport komisji Ligii Narodów potwierdzał geograficzną przynależność wysp do Finlandii, ale równocześnie podnosił sprawę odpowiedniego traktowania wyspiarzy przez fińską większość. Odpowiednio do konkluzji wypływających z raportu, Liga Narodów w rezolucji z 24 czerwca 1921 roku uznała władzę Finlandii nad archipelagiem oraz zaleciła wypracowanie kompromisu dotyczącego statusu wyspiarzy w drodze dwustronnych negocjacji Szwecji i Finlandii. Umowę taką rządy obu krajów wynegocjowały już wcześniej, wobec czego dołączona została do rezolucji w postaci aneksu. Przewidywała ona, że Wyspy nie są zobowiązane do utrzymywania szkół, w których język nauczania jest inny niż szwedzki, prawo nabywania i posiadania nieruchomości na Wyspach oraz prawa wyborcze przysługują wyłącznie ich stałym mieszkańcom, osoba gubernatora Wysp Alandzkich będzie przed mianowaniem przez prezydenta uzgadniana z Landstingiem (parlamentem regionalnym), a autonomia może wydawać na swoje potrzeby $50 \%$ dochodów z podatków od ziemi13. Oczywiście te pierwotne umowy i ustawy były wielokrotnie nowelizowane i zmieniane, nie zmieniało to jednak w żaden sposób terytorialnej przynależności Wysp Alandzkich do Finlandii, a jedynie kształtowało zakres i formy ochrony odmienności językowej i kulturowej wyspiarzy, rzutując również na sytuację mniejszości szwedzkojęzycznej w pozostałej części Finlandii14.

\section{ODRĘBNOŚĆ}

Do początków XIX wieku mieszkaniec Wysp Alandzkich był poddanym króla Szwecji, z krajem tym się identyfikował i z jego kulturą utożsamiał. O takiej tożsamości decydował cały kompleks czynników natury geograficznej, historycznej, językowej czy gospodarczej. To właśnie protoplaści dzisiejszych Szwedów - plemiona Swaewów i Gotów około VIII wieku kolonizowały archipelag w pierwszym etapie wielkiej ekspansji Wikingów sięgającej od Ameryki Północnej po Bliski Wschód ${ }^{15}$. Tędy prowadził szlak handlowy Waregów wiodący do jeziora Ładoga i dalej na wschód i południe aż do Bagdadu. To przez Wyspy Alandzkie prowadził szlak pierwszej krucjaty na tereny dzisiejszej Finlandii, poprowadzonej przez króla Eryka IX przy udziale biskupa Henryka. Wyprawy, która poza Kroniką Eryka nie jest udokumentowana historycznie, ale bezsprzecznie stanowi ważny element szwedzkiej kultury narodowej. Równocześnie, jako symboliczny początek dzieła chrystianizacji plemion fińskich i karelskich, jest też wydarzeniem świadczącym o świętości króla Eryka - dzisiejszego patrona Szwecji ${ }^{16}$. Archipelag znajdował się prawdopodobnie w składzie kształtującego się dopiero państwa szwedzkiego już około roku 1000, za panowania Olafa, syna Eryka Zwycięzcy ${ }^{17}$. Choć prawdą jest, co podnosili Finowie przed Ligą Narodów, że zgodnie z kościelnym podziałem administracyjnym, od czasu założenia diecezji w Turku (czyli od krucjaty) parafie na wyspach do niej należały i że w XIV wieku

\footnotetext{
13 M. Sobczyński, Rola i miejsce Wysp Alandzkich..., s. 132-133.

14 Przykładem może być ustawa o języku przyjęta przez parlament Finlandii w 1922 roku, która ustanowiła fiński i szwedzki językami równoprawnymi i zobowiązywała urzędników państwowych do ich znajomości. Była ona odpowiedzią na żądania Ludowej Partii Szwedzkiej, która reprezentowała mniejszość szwedzką w Finlandii i domagała się przyznania autonomii administracyjnej na wzór autonomii Wysp Alandzkich tym gminom, w których Szwedzi stanowili większość. Por.: O. Jussila, S. Hentilä, J. Nevakivi, Historia polityczna Finlandii..., s. 161-162.

15 T. Cieślak, Historia Finlandii, Wrocław 1983, s. 19

16 Od końca XII wieku rozpoczął się jego kult i dziś jako św. Eryk jest patronem Szwecji. Niestety źródła historyczne nie potwierdzają legend o wyprawie, a informacje o niej znajdujemy dopiero w pochodzącej z XIV wieku Kronice Eryka. Por.: T. Cieślak, Historia Finlandii..., s. 22-23.

17 A. Kersten, Historia Szwecji, Wrocław-Warszawa-Kraków-Gdańsk 1973, s. 42.
} 
rejon wszedł w skład okręgu podatkowego w Turku, to przecież nie można zapominać, że miasto to nosiło wówczas nazwę Åbo i było w rzeczywistości szwedzką kolonią po drugiej stronie Zatoki Botnickiej. Wydaje się, że Wyspy Alandzkie traktowane były przez jej mieszkańców jako Szwecja i tak też postrzegane przez mieszkańców Upplandu czy Norrlandu. Kierując się słowami E. Gellnera: „Ludzie pragną być zjednoczeni z tymi, którzy uczestniczą w tej samej kulturze. Państwa pragną zatem rozciągnąć swe granice tak, by obejmowały daną kulturę: pragną jej strzec i ją popierać w zasięgu swej władzy. Fuzja woli, kultury i państwa staje się normą..."18, należy uznać, że aż do początków XIX wieku, a więc do przyłączenia do nowo powstałego Wielkiego Księstwa Finlandii, wyspiarze byli Szwedami ${ }^{19}$ i z narodem tym dzielili losy historyczne, walczyli w wojnach dowodzeni przez swych pobratymców, uczestniczyli w elekcji króla, wsłuchiwali się w słowa kaznodziejów głoszących nowe, luterańskie przekonania. Tu także, zapewne z powodu geograficznego oddalenia, w twierdzy Kastelholm przetrzymywany był pozbawiony korony Eryk XIV.

Kiedy na początku XIX wieku archipelag zajęty został przez Rosjan i przyłączony do Wielkiego Księstwa, splot wydarzeń międzynarodowych i rozkład sił w basenie Morza Bałtyckiego uniemożliwiał skuteczne dążenie do ponownego połączenia z macierzą. Ale w wyniku zmiany przynależności państwowej Alandczycy stali się poddanymi władcy imperium o odmiennej kulturze, języku, wyznaniu, odmiennej kulturze politycznej oraz nieporównywalnej pozycji i władzy cara. Jak pisał S. Huntington, cywilizację prawosławną odróżnia: „... bizantyjski rodowód, odrębna religia, dwieście lat panowania tatarskiego, biurokratyczny despotyzm oraz ograniczony kontakt z Renesansem, Reformacją, Oświeceniem i innymi zjawiskami tak ważnymi dla Zachodu"20. Musiało to budzić poczucie odrębności wobec obcych, którzy przybyli na Wyspy i zaczęli budować twierdzę Bomarsund dla umocnienia swego panowania ${ }^{21}$. Zbliżałoby to niewątpliwie wyspiarzy do mieszkańców pozostałej części księstwa, ale tam coraz silniej zaznaczała się nowa, fińska odrębność kulturowa22. Stanęli zatem mieszkańcy Alandów przed podwójnym wyalienowaniem, obok obcości imperium rosyjskiego pogłębiała się także odrębność w stosunku do Finów i Finlandii. Wyspy Alandzkie okazały się zarówno w skali księstwa, jak i imperium peryferyjnym rejonem o marginalnym znaczeniu gospodarczym, obcym języku i zwłaszcza po wojnie krymskiej, w związku z demilitaryzacją i neutralizacją archipelagu, nikłym znaczeniu militarnym. W efekcie kształtować się zaczęła, obok tożsamości szwedzkiej, odrębna tożsamość regionalna jako forma tożsamości oporu. Opierała się ona oczywiście na odmienności religijnej i językowej, ale jak się wydaje - jej ważnym elementem była nostalgia za "dawnymi, lepszymi czasami", gdy Wyspy Alandzkie przynależały do królestwa Szwecji23.

18 E. Gellner, Narody i nacjonalizm, tłum. T. Hołówka, Warszawa 1991, s. 71-72.

19 Pomijam tu próby odpowiedzi na pytania, czym jest naród i od kiedy można mówić o istnieniu narodów, jako wykraczające poza ramy niniejszego opracowania. Niezwykle ciekawy, choć zapewne przerysowany obraz Szwedów odnaleźć można w: E. Lewandowski, Pejzaż etniczny Europy, Warszawa 2005, s. 110-121.

20 S. Huntington, Zderzenie cywilizacji, tłum. H. Jankowska, Warszawa 2004, s. 56. Przyjmując paradygmat Samuela Huntingtona, możemy stwierdzić, że po 1809 r. linia podziału pomiędzy cywilizacją zachodnią a prawosławną z centrum w Moskwie przesunęła się na Zatokę Botnicką, a przynajmniej, że Finlandia (a także część Polski) stała się strefą buforową pod zarządem cywilizacji prawosławnej.

21 Twierdza Bomarsund wznoszona była od 1829 roku i miała wzmocnić rosyjskie panowanie nad archipelagiem oraz zapewnić bezpieczeństwo portowi, który miał się stać trzecim, obok Sveaborga i Turku, głównym portem rosyjskiej floty bałtyckiej. Twierdza została zdobyta i zniszczona przez wojska francusko-brytyjskie w czasie wojny krymskiej. Patrz: J. Gozdawa-Gołębiowski, Od wojny krymskiej do batkańskiej, Gdańsk 1985, s. 27-29.

22 T. Cieślak, Historia Finlandii..., s. 136-148.

23 B. Jałowiecki klasyfikuje regionalizm jako złożony przypadek tożsamości oporu, odróżniając go od innych jej przykładów, takich jak nacjonalizm czy antymodernizm. Choć bez wątpienia elementy każdego z tych przykładów tożsamości oporu można odnaleźć w pozostałych. Por.: B. Jałowiecki, Globalizacja, lokalność, tożsamość, [W:] W. Wesołowski, J. Włodarek (red.), Kregi integracji i rodzaje tożsamości. Polska, Europa, Świat, Warszawa 2005, s. 116-117. 
Jak pisał Marek Sobczyński, „Można zatem domniemywać, że gdyby Liga Narodów w 1921 r. podjęła inną decyzję i Alandy znalazłyby się w granicach Szwecji, Alandczycy nie ukształtowaliby w sobie poczucia odmienności. Nie musieliby na każdym kroku walczyć o większą niezależność i manifestować swej odrębności i zapewne nie wykształciliby swoistych cech, po prostu byliby Szwedami"24. Trudno się nie zgodzić z tą opinią, choć bez wątpienia na budowę własnej tożsamości znaczący wpływ miały także wcześniej występujące czynniki geograficzne i historyczne, a jej bardziej uświadomionych początków należy poszukiwać w XIX wieku, w okresie przynależności do imperium rosyjskiego. W efekcie, przytoczony pogląd wydaje się bardzo prawdopodobny, a w przypadku odmiennego rozstrzygnięcia Ligi Narodów różnice pomiędzy Alandczykiem a mieszkańcem Upplandu byłyby zapewne nie większe niż pomiędzy Polakiem z Galicji i Kongresówki. Oczywiście istniałaby, tak jak istnieje dzisiaj, przynależność do Wysp Alandzkich jako małej ojczyzny, ale przeciętny Alandczyk miałby przede wszystkim szwedzką tożsamość narodową. Jednak polityczne rozstrzygnięcia początku lat dwudziestych XX wieku doprowadziły do wzrostu aktywności społecznej i politycznej, a przez to i świadomości Alandczyków, kształtując ich tożsamość i doprowadzając do wyodrębnienia się specyficznego dla Wysp regionalnego uniwersum symbolicznego ${ }^{25}$.

Mówiąc o Wyspach i o ich specyfice, ich mieszkańcy zwracają uwage na trzy podstawowe cechy charakterystyczne: autonomie, demilitaryzację i język szwedzki26. Szczególnie ten ostatni element jest czynnikiem silnie wyodrębniającym populację archipelagu, zwłaszcza jeżeli pamiętać będziemy, że język szwedzki należy do grupy germańskiej (nordyckiej), natomiast fiński do ugrofińskiej27. Wśród mieszkańców, aż 24684 (91,7\%) osoby deklarują, że ich językiem ojczystym (rodzinnym) jest szwedzki, a zaledwie 1352 (5\%), że fiński ${ }^{28}$. Cecha ta najsilniej odróżnia region od reszty Finlandii, gdzie proporcje są odwrotne: fiński - 91\%, szwedzki - 5,5\% ${ }^{29}$. Równocześnie w wyniku oddzielenia geograficznego i politycznego Wysp, używany na nich język szwedzki nie przeszedł zmian analogicznych do używanego w Szwecji, a jednocześnie wystawiony był na wpływ dominującego w kraju języka fińskiego. Spowodowało to ukształtowanie się specyficznego dla Wysp dialektu szwedzkiego w procesie analogicznym na przykład do tego, jakim podlegał język polski używany dziś przez Polaków na terenie Ukrainy czy Białorusi. Decydujący wpływ na utrwalanie i rozpowszechnienie języka szwedzkiego na Wyspach miała i ma, obok składu mieszkającej tu populacji, jego prawna ochrona, a zwłaszcza wymóg jego znajomości dla uzyskania prawa domicylu oraz konieczność używania go w sądach, urzędach i w życiu codziennym. Szwedzki jest także wyłącznym językiem nauki w szkołach, natomiast fiński ma status przedmiotu dodatkowego. W związku z takimi regulacjami po-

- • • •

24 M. Sobczyński, Rola i miejsce Wysp Alandzkich..., s. 142.

25 M.S. Szczepański do wartości współtworzących regionalne uniwersum symbolicznego zalicza: indywidualną identyfikację z regionem i jego kulturą, poczucie odrębności i podział na My-Oni, specyfikę aktywności politycznej i systemu partyjnego, przypisanie do miejsca i przestrzeni, świadomość dziedzictwa kulturowego i rozumienie jego symboli, związek z dziejami regionu i jego bohaterami oraz instytucjami, wspólnotę gospodarowania i wreszcie istnienie specyficznych form budownictwa. Por.: M.S. Szczepański, Społeczności lokalne i regionalne a ład kontynentalny i globalny, [w:] W. Wesołowski, J. Włodarek (red.), Kregi integracji i rodzaje tożsamości..., s. 132.

26 Np. Åland in Brief..., s. 3 i 5.

27 E. Lewandowski, Pejzaż etniczny Europy..., s. 28. Jest to zatem różnica analogiczna do różnicy pomiędzy językiem niemieckim a węgierskim.

28 Statistisk årsbok för Åland 2007, ÅSUB, Mariehamn 2007, s. 46. Dodajmy, że wśród innych języków używanych przez mieszkańców, na czoło wysuwają się estoński (94 osoby), angielski (80 osób) i łotewski (77 osób), natomiast najsłabiej reprezentowane są islandzki (7 osób) oraz węgierski i francuski (po 10 osób). Język polski jako ojczysty wskazało 31 grudnia 2006 roku 34 mieszkańców Wysp Alandzkich, a liczba ta wzrosła z 4 w roku 1990 i 17 w 2003 roku.

29 Finland in Figures/Population, [w:] www.stat.fi - oficjalna strona Urzędu Statystycznego Finlandii. 
jawiła się dyskusja, czy osoby mieszkające na Wyspach Alandzkich, dla których językiem macierzystym jest fiński, w istocie nie są dyskryminowane ${ }^{30}$. Wsparciem dla języka jest także funkcjonowanie szwedzkojęzycznych mediów, w szczególności regionalnego radia publicznego nadającego wyłącznie po szwedzku, a także programów w tym języku w publicznej telewizji fińskiej. Oczywiście przez satelitę, ale także w ofercie operatorów kablowych dostępne są szwedzkie programy telewizyjne.

Wskazana różnica w przynależności Szwedów do ludów indoeuropejskich, a Finów do ugrofińskich powinna determinować znaczące różnice nie tylko językowe, ale również w innych elementach kultury obu narodów. Jednak kolonizacja i wielowiekowa obecność szwedzka we współczesnej Finlandii, wspólna historia oraz silne związki społeczne, polityczne i gospodarcze spowodowały, że kraje te mają wiele wspólnych cech i należą do tej samej skandynawskiej grupy kulturowej31. Brak jest więc między nimi i wewnątrz nich znaczących różnic w zakresie filozofii bytu, postrzegania człowieka czy świata. W obu także dominującym wyznaniem jest luteranizm, upowszechniany za czasów dynastii Wazów $^{32}$. W efekcie na plan pierwszy wysuwają się czynniki mniej znaczące, często uwarunkowane regionalnie, poprzez tradycyjny schemat życia, wykonywany zawód, przynależność do określonego miejsca i życie w określonej grupie społecznej cechującej się większym lub mniejszym poziomem samoidentyfikacji.

Dla Wysp Alandzkich elementem silnie wyodrębniającym wydaje się położenie geograficzne. Z jednej strony wyspy były zawsze pomostem pomiędzy wybrzeżem szwedzkim i fińskim, z drugiej były przestrzennie oddzielone, a komunikacja z lądem czy wymiana informacji wymagały użycia statków lub wykorzystania lodu łączącego wyspy z rejonem Turku, który zwykle skuwa tę część Zatoki Botnickiej w grudniu i topi się w kwietniu ${ }^{33}$. Zamykało to mieszkańców wewnątrz ich małej ojczyzny, której granice mentalne pokrywały się z tymi wyznaczonymi przez wode. Oddzielenie to miało znaczenie zarówno regionalne jak i lokalne. Do lat pięćdziesiątych XX wieku 25\% populacji archipelagu rozsiane było poza główną, największą wyspą (Fasta Aland), a tylko 10\% mieszkało w Mariehamn. Przez kolejnych 20 lat następował szybki wzrost liczby osób zamieszkujących stolicę regionu i spadek populacji na terenach słabiej zurbanizowanych. W efekcie, choć populacja archipelagu wynosi dziś 27 tys., to poza Fasta Aland mieszkają zaledwie 2 tys. osób. Proces ten zaowocował opuszczeniem niektórych wysp, a liczba wysp zamieszkanych zmalała ze 100 około 1900 roku³ $^{34}$, do 60 obecnie. Oznacza to, że życie dużej części mieszkańców koncentrowało się, a częściowo wciąż koncentruje, nawet nie w skali regionalnej, bo to ma miejsce głównie na Fasta Aland, ale w małych lokalnych wspólnotach rozsianych na dziesiątkach wysp i wysepek.

Położenie geograficzne oraz warunki środowiskowe i społeczne narzucały również specyficzny tryb życia. Społeczność Wysp była zawsze bardzo silnie związana z morzem, od którego przychylności zależat jej los. Przez wieki swej historii Alandczycy byli marynarza-

30 Więcej na ten temat np. w: L. Hannikainen, Cultural, linguistic and educational rights in the Åland Island. An analysis in international law, Helsinki 1993, s. 38.

31 Do tej samej grupy należą także pozostałe kraje nordyckie: Islandia, Norwegia i Dania. Por. np.: J. Wojtanowicz, Europejska przestrzeń geograficzno-kulturowa, Lublin 2008, s. 102-103. W stosunkach międzynarodowych jej odzwierciedleniem jest Rada Nordycka, do której należą: Dania, Finlandia, Islandia, Norwegia i Szwecja, a dodatkowo także na prawach członków trzy autonomie: Wyspy Alandzkie (Finlandia) oraz Grenlandia i Wyspy Owcze (Dania).

32 88,5\% mieszkańców Wysp Alandzkich deklaruje wyznanie luterańskie. Patrz: Statistisk årsbok för Åland 2007..., s. 46

33 Pierwszy telegraf optyczny umożliwiający szybką wymianę informacji z wybrzeżem Szwecji wybudowano w końcu XVIII wieku. Patrz: Åland in Brief..., s. 21.

34 Tamże, s. 5. 
mi i rybakami. Także dziś 17,5\% aktywnych zawodowo mieszkańców zatrudnionych jest w transporcie, przy czym pod tą statystyczną pozycją ukrywa się przede wszystkim praca na statkach oraz na promach codziennie kursujących między Wyspami Alandzkimi a Szwecją, Finlandią i Estonią, a znacząca grupa utrzymuje się z obsługi przypływających tu statkami i jachtami turystów ${ }^{35}$. Symbolicznym elementem świadczącym o związku z wodą i morzem jest nazwa Aland, którą wywodzi się ze starogermańskiej Ahvaland - wodna ziemia, skąd przeniknęła do języka fińskiego, w którym Wyspy noszą nazwę Ahvenanmaa i do szwedzkiego, gdzie została przez wieki skrócona do Aland ${ }^{36}$. Niebezpieczeństwa zawodów związanych z morzem i konieczność radzenia sobie z przeciwnościami losu w małych, zamkniętych społecznościach uwrażliwiły mieszkańców na los pozostałych członków ich wspólnot, utrwalając zasady samopomocy, a równocześnie wymuszając poszukiwanie sposobów jak najbardziej efektywnego wykorzystania dostępnych zasobów. Zasada ta ma dziś swoje odzwierciedlenie w statucie regionu, który daje władzom autonomii kompetencje do przekazywania w odpłatne użytkowanie innym osobom, niewykorzystanych, a pozostających w prywatnych rękach gospodarstw rolnych i wód, dla ich bardziej efektywnego wykorzystania ${ }^{37}$.

Wyodrębnienie regionu widoczne jest również na płaszczyźnie gospodarczej. Pomijając wcześniej zasygnalizowaną specyficzną strukturę zawodową, ma ona dwa szczególnie istotne aspekty. Jednym z nich jest autonomia finansowa, która pozostawia w gestii regionu $0,45 \%$ przychodów budżetu Finlandii, co odpowiada proporcji liczby mieszkańców archipelagu do ogółu mieszkańców całego kraju ${ }^{38}$. Władze regionu samodzielnie decydują o przeznaczeniu pieniędzy, a mogą również starać się o fundusze dodatkowe. Drugim jest specyficzna sytuacja podatkowa archipelagu. Pomimo przynależności wraz z Finlandią od 1 stycznia 1995 roku do Unii Europejskiej, w zakresie podatków region pozostaje tzw. terytorium trzecim, a więc nie musi ich dostosowywać do zasad wspólnotowych ${ }^{39}$. W efekcie podstawą budżetu regionu są przychody od turystów, którzy traktują archipelag i pływające nań promy jak wielką strefę bezcłową (bezakcyzową), często nawet nie wysiadając w porcie docelowym. Napływ turystów jest szczególnie widoczny w okresie letnim, kiedy liczba połączeń promowych rośnie dwukrotnie, z 20 do 40 dziennie, a pracodawcy i rząd autonomii poszukują pracowników poza Wyspami do pracy na promach, obsługi ruchu turystycznego, pracy w hotelach i sklepach. Podobnie rzecz się ma w służbie zdrowia, przed którą stoją dziś daleko większe wyzwania niż dbanie o kondycję 27-tysięcznej społeczności autochtonów ${ }^{40}$. Jednocześnie warto pamiętać, że Wyspy cieszą się najniższym wśród państw nordyckich poziomem bezrobocia, a PKB regionu w przeliczeniu na głowę mieszkańca znacznie przewyższa PKB per capita Finlandii ${ }^{41}$.

Jednak napływ obcych, choćby tylko sezonowy, musi przekładać się na wzrost poczucia zagrożenia i pojawianie się izolacjonizmu, a na drugim biegunie - na rozmywanie

35 Statistisk årsbok för Åland 2007..., s. 128.

36 P. Virrankoski, Suomen historia, Helsinki 2001, s. 59.

37 Art. 18 p. 18 Statutu Wysp Alandzkich. Tekst jednolity w języku polskim w: G. Bonusiak (wstęp i tłumaczenie), Statut Wysp Alandzkich, Rzeszów 2009.

38 Art. 45-47 Statutu Wysp Alandzkich.

39 Art. 57 Protokołu w sprawie traktatów o przystąpieniu i aktów przystąpienia Królestwa Danii, Irlandii oraz Zjednoczonego Królestwa Wielkiej Brytanii i Irlandii Północnej, Republiki Greckiej, Królestwa Hiszpanii i Republiki Portugalskiej oraz Republiki Austrii, Republiki Finlandii i Królestwa Szwecji, [w:] Dziennik Urzędowy Unii Europejskiej z 16.12.2004, C 310/267.

40 W 2006 roku odnotowano 500 tys. noclegów w hotelach i pensjonatach osób zamieszkałych poza archipelagiem, oraz 30 tys. dni postojów w marinach jachtów, których port macierzysty leży poza Wyspami. Statistisk årsbok för Åland $2007 \ldots$, s. 111

41 W 2004 roku 32,5 tys. EUR dla Wysp Alandzkich w porównaniu z 25,5 tys. EUR dla całej Finlandii. Tamże, s. 237. 
jednorodności i spoistości kulturowej Wysp. Wydaje się, że właśnie owo poczucie zagrożenia spowodowało, zgodnie z zasadami dynamiki konfliktów, swoiste "zwarcie szeregów", którego objawami było poszukiwanie podobieństw w swoim kręgu i ujednolicanie sposobów myślenia i zachowań, a z drugiej - niechęć wobec obcych i poszukiwanie w nich tego, co złe. Jest to wyraźnie widoczne również dzisiaj, kiedy względy ekonomiczne zmuszają do otwartości na świat i przyciągania obcych, a społeczne i polityczne nie tylko umożliwiają, ale wręcz zachęcają do budowania barier, wzmacniania odrębności, utrwalania specyfiki kulturowej i niechęci do obcych. Jednak w podziale My - Oni rysuje się bardzo wyraźne stopniowanie kategorii Oni, a więc przełamany jest schemat czarnobiałego świata, gdzie wszystko, co nas otacza jest albo dobre - czyli do nas podobne, albo złe - czyli obce i bez wątpienia gorsze. Przeprowadzane na Wyspach badania pokazują zależność pomiędzy odległością kulturową obcych a niechęcią do nich, jak też postrzeganym przez imigrantów poziomem niechęci i dyskryminacji ze strony autochtonów na polu aktywności społecznej czy zawodowej. Zbiorowością najlepiej postrzeganą, a równocześnie najrzadziej spotykającą się z przejawami nietolerancji, są Szwedzi i Finowie, a zaraz za nimi osoby pochodzące z pozostałych krajów nordyckich, a więc należące do tej samej skandynawskiej grupy kulturowej. Tuż za nimi plasują się mieszkańcy państw nadbałtyckich, zwłaszcza Łotwy i Estoni. Na drugim biegunie sytuują się osoby z odległych kultur, odmienne rasowo i wyznaniowo, a pochodzące z Azji, Bliskiego Wschodu i Afryki. Nieco lepiej postrzegane są osoby pochodzące z państw byłego Związku Radzieckiego, choć jak wspomnieliśmy, państwa nadbałtyckie są wśród nich traktowane wyjątkowo dobrze. W środku plasują się pozostałe kraje Europy Zachodniej oraz nieco niżej od nich - Europy Środkowej i Wschodniej, choć różnice między tymi kategoriami nie są znaczące ${ }^{42}$. Jednak obok przynależności do innych grup kulturowych najważniejszym czynnikiem różnicującym status obcych na Wyspach jest znajomość języka szwedzkiego. To ona jest elementem najsilniej utrudniającym udział imigrantów w codziennym życiu mieszkańców regionu, a co za tym idzie najsilniej alienującym. Co szczególne, dotyczy to również obywateli Finlandii nieposługujących się językiem szwedzkim.

Specyficzna historia regionu wpłynęła także na instytucje polityczne i, szerzej, na system polityczny, jaki ukształtował się na Wyspach. Dzięki autonomii politycznej i możliwości stanowienia własnego prawa Alandczycy wytworzyli własny system organów i zachowań politycznych, pozwalających im na kultywowanie odrębności od Helsinek. W wyłącznych kompetencjach regionu pozostają: oświata, kultura, ochrona zabytków, ochrona zdrowia, ochrona środowiska, transport wewnętrzny, bezpieczeństwo publiczne (w tym służby mundurowe), poczta, środki masowego przekazu. W tym zakresie organem stanowiącym jest parlament Wysp Alandzkich (Lagting), a organem władzy wykonawczej rząd Wysp Alandzkich (Landskapsregering), powoływany przez Lagting, zaś kompetencje autonomii oraz system jej organów reguluje Statut Wysp Alandzkich ${ }^{43}$. Szczególny tryb powoływania i wybierania na urzędy w autonomii, a także zakres biernego i czynnego prawa wyborczego powodują, że dla osoby z zewnątrz, w szczególności nieznającej języka

42 Na temat integracji obcych, ich postrzegania przez Alandczyków oraz o tym, jak imigranci postrzegają otwartość i tolerancję mieszkańców Wysp, w raportach: B. State, Immigrant Integration on Aland - an exploratory study, Report from the Åland Islands Peace Institute No 2-2007, Mariehamn 2007; P. Granholm, Översikt av lagstiftning och policy gällande integrationen av inflyttade i Finland och på Åland, Report from the Åland Islands Peace Institute No 2-2009, Mariehamn 2009; "Olika behandling i lika situation": Om diskriminering i det åländska samhället, ÅSUB, Mariehamn 2007.

43 Szerzej o politycznych i prawnych podstawach istnienia i funkcjonowania autonomii Wysp Alandzkich, w: G. Bonusiak, Między Szwecją a Finlandią. Polityczno-prawne wyznaczniki szczególnego statusu Wysp Alandzkich, [w:] O. Suchomłynow (red.), Fenomien kulturnych pogranycz: suczasni tendenciji / Fenomen pogranicz kulturowych: wspótczesne tendencje, Donieck 2008. 
szwedzkiego wybór i piastowanie jakiejkolwiek funkcji publicznej jest niemożliwe, choć pewne koncesje zostały tu uczynione dla obywateli państw nordyckich. W efekcie, po początkowym działaniu mieszkańców i ich liderów w Ludowej Partii Szwedzkiej jednoczącej po pierwszej wojnie światowej pod swymi skrzydłami wszystkich czujących się Szwedami mieszkańców Finlandii, stopniowo zaczęło dochodzić do kształtowania się na Wyspach odrębnej sceny politycznej. Istniejące partie polityczne są niezależne od swych ogólnokrajowych odpowiedników i reprezentują pełne spektrum poglądów mieszkańców regionu. Przez wiele lat w kolejnych wyborach do regionalnego parlamentu najlepsze wyniki osiągata ludowa partia Ålands Center, a na drugim miejscu plasowali się liberałowie z Liberalerna på Åland, choć od wyborów z 2007 roku ta kolejność się odwróciła ${ }^{44}$. Po prawej stronie sceny politycznej występują jeszcze, zdobywający największe poparcie w latach dziewięćdziesiątych ubiegłego wieku, konserwatywni liberałowie pod szyldem Frisinnad Samverkan i istniejący od lat osiemdziesiątych konserwatyści z Obunden Samling. Daleko słabiej reprezentowana jest lewa strona sceny politycznej, skupiona w Ålands Socialdemokrater. Obok swej odrębności, regionalny system partyjny ma dwie cechy charakterystyczne. Jedną jest słabość socjaldemokratów, którzy zdobywają zwykle od 3 do 6 miejsc w liczącym 30 miejsc parlamencie. Sytuacja taka odzwierciedla relatywnie słabe zurbanizowanie i uprzemystowienie regionu, a co za tym idzie nikłość środowisk będących naturalnym zapleczem dla partii lewicowych oraz przywiązanie mieszkańców do tradycji, zakorzenienie, a co za tym idzie typową tendencje do wspierania partii o bardziej konserwatywnym programie. Drugą cechą charakterystyczną jest istnienie zdobywającej niewielkie poparcie, ale obecnej w parlamencie partii opowiadającej się za pełną suwerennością Wysp i odrzucającą zarówno związek z Finlandią, jak i ze Szwecją ${ }^{45}$. Dążenia niepodległościowe pojawiają się także wśród przedstawicieli pozostałych partii politycznych regionu, a szczególnym wsparciem cieszą się wśród konserwatystów z Obunden Samling.

O większym znaczeniu spraw regionalnych i lokalnych ponad ogólnopaństwowymi w świadomości mieszkańców świadczyć może mniejsza frekwencja w wyborach do parlamentu krajowego. O ile w elekcji do parlamentu regionalnego i w wyborach samorządowych udział bierze średnio około $67 \%$ uprawnionych, to w wyborach do parlamentu krajowego wskaźnik ten jest mniejszy o około 10 punktów ${ }^{46}$. Sytuacja ta budzi zdziwienie $\mathrm{w}$ zestawieniu z prawem wyborczym Finlandii, zgodnie z którym Wyspy Alandzkie w wyborach parlamentarnych tworzą odrębny okręg wyborczy i nominują jednego przedstawiciela ${ }^{47}$. W efekcie wybory te na Wyspach są typową elekcją większościową: ze zgłoszonych kandydatów osoby posiadające prawo głosu wybierają jednego deputowanego spośród mieszkańców regionu. Kandydaci są świetnie znani w lokalnej społeczności i nie mogą chować się za szyldami wspierających ich partii politycznych. Deputowany jest głosem mieszkańców Wysp Alandzkich na forum Eduskunty i nie reprezentuje żadnej z działających w Finlandii poza Wyspami partii politycznych, choć w bieżących działaniach parlamentu zwykle współdziała z Ludową Partią Szwedzką w Finlandii (Svenska Folkepartiet i Finland). Na kandydatów tej właśnie partii mieszkańcy oddają swe głosy w wyborach do Parlamentu Europejskiego, choć frekwencja w nich jest bardzo niska ${ }^{48}$.

44 Åland in figures 2009, ÅSUB, Mariehamn 2009, s. 24.

45 W wyborach z 2003 roku partia startowała po raz pierwszy i otrzymała ponad 6\% głosów, w wyborach z 2007 roku otrzymała ponad 8\% głosów. W obu przypadkach dało to dwa miejsca w liczącym 30 deputowanych parlamencie. Patrz: Åland in figures 2009..., s. 24 i Statistisk årsbok för Åland 2007.., s. 218.

46 Tamże, s. 227

47 M. Grzybowski, Eduskunta. Parlament Finlandii, Warszawa 2001, s. 14

48 W roku 2004 na Ludową Partię Szwedzką swój głos oddało 72\% głosujący na Wyspach, jednak frekwencja wynosiła zaledwie 35,5\% uprawnionych. Patrz: Statistisk årsbok för Åland 2007..., s. 228. 
Autonomia regionalna, choć nie oznacza pełnej suwerenności, to jednak umożliwia posiadanie symboli własnej odrębności i niezależności przynależnych zwykle państwu. I tak Wyspy Alandzkie posiadają własną flagę, herb i hymn. Herb pochodzi z 1562 roku i pierwotnie był nadany Olandii, jednak na przestrzeni wieków przypisany został Wyspom Alandzkim ${ }^{49}$. Hymnem autonomii jest „Pieśń o wyspiarzach alandzkich” (Ålänningens sång), opiewająca piękno archipelagu oraz odwagę i honor jego mieszkańców, a jej pierwsze publiczne wykonanie miało miejsce na festiwalu piosenki, który odbywał się w roku 1922 w Mariehamn. Symboliczna jest historia flagi, która przedstawia czerwony krzyż skandynawski z żółtym obrzeżem na niebieskim tle i stała się oficjalnym symbolem regionu w 1954 roku. Wcześniej w użyciu było kilka nieoficjalnych wersji i gdy rozpoczęła się dyskusja nad flagą oficjalną, największe poparcie na Wyspach znalazła koncepcja analogiczna do dzisiejszej, jednak z niebieskim krzyżem skandynawskim w środku. Została ona odrzucona przez prezydenta Finlandii jako zbyt podobna do flagi Królestwa Szwecji; zdecydowano, że środkowy krzyż będzie miał kolor czerwony nawiązujący do koloru herbu Finlandii. Zatem symbolicznie wyeksponowano terytorialną przynależność do Finlandii, wycofując się z wywołującej polityczne kontrowersje koncepcji podkreślającej związek Wysp ze Szwecją ${ }^{50}$. Symbole te zobaczyć i usłyszeć można na ulicach zwłaszcza z okazji trzech głównych i również specyficznych dla regionu świąt: w Dniu Autonomii (9 czerwca), Dniu Demilitaryzacji (30 marca) i Dniu Flagi (ostatnia niedziela kwietnia). Także na co dzień symbole odrębności są w powszechnym użyciu, a flage znacznie rozpowszechniono od 1993 roku, kiedy na mocy nowego Statutu Wysp Alandzkich zaczęła ona pojawiać się na statkach, których port macierzysty znajduje się na Wyspach, wypierając flagę Finlandii. Dodajmy, że osoby, które dopływając do portów na archipelagu nieopatrznie wywieszą flagę Finlandii zamiast miejscowej, często spotykają się z bardzo nieprzychylnymi reakcjami służb portowych ${ }^{51}$. Obok wymienionych symboli o specjalnym statusie Wysp świadczy własna poczta, która emituje od 1984 roku znaczki z nazwą Åland, z uwagi na niewielki nakład cenione przez filatelistów na świecie, a także przypisany im skrót ax używany w internecie oraz widoczny na samochodach. Na tablicach rejestracyjnych samochodów zarejestrowanych na Wyspach występuje zresztą równocześnie flaga, herb i nazwa Åland, a numery rejestracyjne rozpoczynają się od liter $\AA$ L.

Alandczycy są specyficzną zbiorowością wyraźnie odrębną od Finów, ale również nie tożsamą ze Szwedami. Mają odrębną historię i upamiętniające ją święta, własny mit założycielski opowiadający o tym, jak na początku lat dwudziestych ubiegłego wieku kształtowała się ich obecna sytuacja polityczna, a także działających wówczas „ojców założycieli" w osobach Juliusa Sundbloma i Carla Björkmana. Mają związane z morzem tradycje i obyczaje oraz specyficzny styl życia z racji wieków pracy na morzu. Cieszą się bogatą gospodarką z nikłym bezrobociem, ale opartą przede wszystkim na handlu i turystach, a z marginalnym udziałem produkcji. Są silnie zainteresowani sprawami regionu, a $w$ daleko mniejszym stopniu kraju i Europy, często zamknięci i skupieni na sobie. Wytworzyli własną odrębną scenę polityczną i własne organy i instytucje, dystansując się od polityki krajowej i europejskiej, choć dbają o własną reprezentację i słyszalność swego głosu na tych forach. Są wreszcie silnie przywiązani do symboli swej odrębności, które wspierają i czynią obecnym w codziennym życiu My zbiorowe, do którego należą. Choć na pierwszy rzut oka są otwarci na obcych i chętnie witają turystów, w rzeczywistości nieufnie patrzą

- • • •

49 Herbarz szwedzki, np.: C. Nevéus, Ny Svensk Vapenbok, Stockholm 1992

50 Więcej na temat flagi, propozycji jej wyglądu i historii, w: E. Tudeer, L. Liljestrom, Ålands flagga, Mariehamn 1994.

51 R. Mielcarek, Mikrokraje Europy, Poznań 2005, s. 51. 
na świat zewnętrzny i z rezerwą traktują osoby zeń pochodzące. Gdy skonfrontujemy te elementy z zaprezentowanym przez M.S. Szczepańskiego rozumieniem tożsamości regionalnej, którą traktuje jako „... szczególny przypadek tożsamości społecznej (zbiorowej) i kulturowej opartej zarazem na tradycji regionalnej (lokalnej), odnoszonej do wyraźnie zdefiniowanego i delimitowanego terytorium, regionu (miejsca), jego specyficznych cech społecznych, kulturowych (symbolicznych), gospodarczych czy nawet topograficznych, wyróżniających go spośród innych regionów(miejsc)"52, istnienie specyficznej regionalnej tożsamości alandzkiej nie pozostawia żadnych wątpliwości. Jednak dodatkowo mamy do czynienia z budowaniem w oparciu o tożsamość regionalną odrębnej tożsamości etnicznej, w sposób oczywisty nie fińskiej, ale coraz wyraźniej także nie szwedzkiej. Proces ten znajduje swe odbicie w skali indywidualnej poprzez poczucie przynależności do specyficznej zbiorowości Alandczyków i odrębności od innych - obcych, choć jak pokazano, kategoria "obcy” jest również niejednorodna i stopniowalna. Psychologicznie wyraża się to w poczuciu bycia Alandczykiem, przy czym nie Szwedem-Alandczykiem czy Finem-Alandczykiem, lecz wyłącznie członkiem regionalnej zbiorowości. Wskazują na to wycinkowe, a przez to niereprezentatywne badania przedstawione przez M. Sobczyńskiego, według których aż 86\% respondentów uznało się za alandczyków, 10,5\% za Finów, a 2,5\% za Szwedów, przy czym współczynnik identyfikacji z tożsamością alandzką rósł znacząco poza stolicą regionu, na terenach gdzie mniej jest imigrantów ${ }^{53}$. Także ustalenia badaczy szwedzkich i fińskich wskazują nie tylko na odrębność wyspiarzy od Finów i Szwedów, ale również odmienność i brak poczucia jedności w stosunku do szwedzkojęzycznej mniejszości zamieszkującej pozostałą część Finlandii, z którą przecież łączą ją losy historyczne ${ }^{54}$.

\section{OCHRONA ODRĘBNOŚCI}

Centralnym, najistotniejszym symbolem formalnie znamionującym przynależność jednostki do społeczności wyspiarzy jest posiadanie przez nią prawa domicylu (hembygdsrätt). Wiąże się z nim szereg praw i przywilejów, których brak niezwykle utrudnia codzienne funkcjonowanie i właściwie uniemożliwia integrację. Jednocześnie sama procedura nadawania prawa domicylu jest na tyle skomplikowana, a związane z nim regulacje na tyle istotne, że można to prawo nazwać regionalnym obywatelstwem. Taka nazwa funkcjonuje zresztą od 1994 roku, a więc od wstąpienia Finlandii do Unii Europejskiej i występuje m.in. w oficjalnych dokumentach $w$ art. 56 protokołu będącego aneksem do traktatu akcesyjnego Finlandii ${ }^{55}$. Z racji urodzenia, prawo domicylu przysługuje osobom mieszkającym na Wyspach Alandzkich, które posiadają obywatelstwo Finlandii i co najmniej jedno z ich rodziców posiada prawo domicylu, natomiast wyłączne prawo nadawania regionalnego obywatelstwa innym osobom ma rząd Wysp Alandzkich. Może być ono nadane wyłącznie obywatelowi Finlandii zamieszkującemu wyspy nieprzerwanie od 5 lat i w odpowiednim

52 M.S. Szczepański, Spoteczności lokalne i regionalne a ład kontynentalny i globalny, [W:] W. Wesołowski, J. Włodarek (red.), Kręgi integracji i rodzaje tożsamości..., s. 128.

53 M. Sobczyński, Rola i miejsce Wysp Alandzkich..., s. 140-141.

54 L. Hannikainen, Cultural, linguistic and educational rights in the Åland Island..., s. 20.

55 Art. 56 Protokołu w sprawie traktatów o przystąpieniu i aktów przystappienia Królestwa Danii, Irlandii oraz Zjednoczonego Królestwa Wielkiej Brytanii i Irlandii Północnej, Republiki Greckiej, Królestwa Hiszpanii i Republiki Portugalskiej oraz Republiki Austrii, Republiki Finlandii i Królestwa Szwecji, [w:] Dziennik Urzędowy Unii Europejskiej z 16.12.2004, C 310/267. 
stopniu znającemu język szwedzki56. W uzasadnionych przypadkach rząd autonomii może odstąpić od pozostałych wymogów i nadać prawo domicylu osobie nieznającej języka i mieszkającej na Wyspach krócej niż 5 lat, jednak wymóg posiadania obywatelstwa Finlandii jest warunkiem wstępnym i musi być spełniony w każdym przypadku, a kandydat musi też w chwili przyznania obywatelstwa mieszkać na Wyspach. Co ciekawe, każdy kto opuści wyspy i zamieszkuje poza nimi przez 5 lat, z mocy prawa traci prawo domicylu.

Posiadanie regionalnego obywatelstwa warunkuje pełen udział jednostki w życiu społecznym, politycznym i gospodarczym regionu, a także zwalnia od odbywania służby wojskowej w związku z demilitaryzacją i neutralizacją archipelagu od czasów wojny krymskiej ${ }^{57}$. Wyłącznie osoba, która posiada prawo domicylu, może być właścicielem nieruchomości na Wyspach, natomiast pozostałe osoby fizyczne oraz osoby prawne, których siedziba znajduje się poza archipelagiem mogą być jedynie użytkownikami (dzierżawcami) ${ }^{58}$. Również tylko obywatel regionu ma możliwość swobodnego wykonywania zawodu oraz prowadzenia działalności gospodarczej. Wreszcie, prawo domicylu warunkuje posiadanie czynnego i biernego prawa wyborczego do parlamentu Wysp Alandzkich i w wyborach samorządowych ${ }^{59}$, a także możliwość zatrudnienia w administracji autonomii i samorządów lokalnych. Zespół tych regulacji powoduje, że niewielka społeczność Wysp Alandzkich może w skuteczny sposób chronić swą odrębność i zabezpieczać swą małą ojczyznę przed zdominowaniem w dowolnej formie przez odmiennych kulturowo obcych. Niemożliwe jest wykupienie ziemi i nieruchomości przez obcych, gdyż nie mogą oni stać się rzeczywistymi właścicielami nieruchomości. Właścicielami, za stosownym odszkodowaniem, przestają być również osoby, które tracą prawo domicylu. Co więcej, autonomia jest wyłącznym spadkobiercą wszystkich nieruchomości położonych na Wyspach, których właściciel zmarł i nie pozostawił innych spadkobierców. Także na własność autonomii przechodzą z mocy prawa wszystkie nieruchomości położone na Wyspach, które przestają być użytkowane przez państwo. Niemożliwa jest także dominacja ekonomiczna i gospodarcza, bowiem prawo restrykcyjnie traktuje osoby nieposiadające prawa domicylu, wprowadzając konieczność zdobywania stosownych pozwoleń i koncesji na prace i prowadzenie działalności gospodarczej. Bez pozwolenia dopuszcza jedynie prowadzenie działalności we własnym miejscu zamieszkania pod warunkiem niezatrudniania nikogo z wyjątkiem współmałżonka i niepełnoletnich dzieci. Wreszcie, niemożliwa jest dominacja polityczna, gdyż parlament Wysp Alandzkich złożony jest wyłącznie z osób posiadających regionalne obywatelstwo, a wszelkie zmiany tej zasady muszą być uchwalone większością kwalifikowaną 2/3 oddanych głosów, co czyni je w rzeczywistości niemożliwymi do przeprowadzenia. Dodatkowo wyłączność właściwości autonomii we wskazanych w Statucie obszarach powoduje, że parlament Finlandii nie ma możliwości swobodnego decydowania o prawie obowiązującym na Wyspach ani o ich statusie, a prezydentowi Republiki, który podpisuje uchwały Lagtingu, przysługuje

56 Zagadnienia związane z prawem domicylu reguluje Statut Wysp Alandzkich w rozdziale II zatytułowanym "Prawo domicylu na Wyspach Alandzkich" (art. 6-12).

57 "Zwolnienie mieszkańców Wysp Alandzkich z odbywania służby wojskowej było jednym z elementów porozumień zawartych pomiędzy Finlandią a Szwecją i Alandczykami po I wojnie światowej. W tym kontekście zasade tą można rozumieć także jako gwarancję, że Alandczycy nie zostaną użyci w ewentualnej wojnie ze Szwecją. W chwili obecnej zasada stosowana jest wobec każdej osoby, która posiada prawo domicylu i zamieszkała na wyspach przed ukończeniem 12. roku życia.

58 Krótko reguluje to zagadnienie art. 10 Statutu Wysp Alandzkich, szerzej Ustawa o prawie własności nieruchomości na Wyspach Alandzkich z 3 stycznia 1975 roku.

59 Na mocy art. 67 Statutu Wysp Alandzkich i w związku z integracją w kręgu krajów nordyckich, bierne i czynne prawo wyborcze w wyborach samorządowych przysługuje również rezydentom mieszkającym na Wyspach Alandzkich i posiadającym obywatelstwo Finlandii lub dowolnego z pozostałych krajów nordyckich. 
prawo ich uchylania wyłącznie wówczas, gdy są sprzeczne z Konstytucją Finlandii lub godzą w bezpieczeństwo państwa. W efekcie niemożliwa jest jednostronna zmiana statusu Wysp, gdyż wszelka zmiana stosownych regulacji w Statucie Wysp Alandzkich lub uchylenie całego aktu wymagają zgodnego rozstrzygnięcia w Lagtingu większością 2/3 oddanych głosów i Eduskuncie w trybie przewidzianym dla zmiany Konstytucji. Wśród kompetencji znajdujących się w wyłącznej właściwości autonomii są zarówno sprawy związane z regionalnymi wyborami i prawem wyborczym, jak też z edukacją, językiem i ochroną kultury na terytorium podlegającym jej jurysdykcji.

Istnienie obu najważniejszych dla sytuacji prawnej na archipelagu aktów prawa krajowego, Statutu Wysp Alandzkich i Ustawy o prawie własności nieruchomości na Wyspach Alandzkich, przewiduje art. 75 Konstytucji Finlandii. Dodatkowo art. 120 stanowi, że: „Wyspy Alandzkie posiadają samorząd zgodnie ze stosownymi uregulowaniami, określonymi w Ustawie o autonomii Wysp Alandzkich", a art. 58 p. 4 upoważnia Prezydenta Finlandii do podejmowania decyzji wskazanych w Statucie Wysp Alandzkich z wyłączeniem decyzji dotyczących finansów autonomii ${ }^{60}$. Zatem aktem najwyższej rangi przewidziano i zagwarantowano istnienie autonomii i specjalnych uregulowań jej statusu, co powoduje, że jej likwidacja wymagałaby zmiany Konstytucji. Co więcej, szczególna sytuacja prawna Wysp Alandzkich znajduje oparcie również w aktach prawa międzynarodowego, w tym w umowach dwustronnych pomiędzy Szwecją a Finlandią. Ma także swe odzwierciedlenie w prawie wspólnotowym, a szczególnie we wspomnianym już protokole będącym aneksem do traktatu akcesyjnego, który wyraźnie dopuszcza stosowanie na terenie Wysp Alandzkich szczególnych regulacji dotyczących prawa do nabywania nieruchomości i prowadzenia działalności gospodarczej wobec osób, które nie posiadają obywatelstwa regionalnego. Choć wydawałoby się, że regulacje te dopuszczają nierówne traktowanie, a nawet dyskryminację osób nieposiadających prawa domicylu, to jednak należy je traktować jako rzeczywistą realizację zapisów art. 22 Karty Praw Podstawowych, który przewiduje ochronę różnorodności kulturowej, językowej i religijnej w Unii Europejskiej ${ }^{61}$.

Istnienie małej, w tym przypadku zaledwie ponaddwudziestotysięcznej społeczności i chęć zachowania jej specyficznej tożsamości w wystarczającym stopniu uzasadniają szczególne regulacje prawne dotyczące jej i zamieszkiwanego przez nią obszaru, a także przekazanie jej jak najszerszych kompetencji do decydowania o sobie i swojej małej ojczyźnie. Choć może to wzmacniać postawy izolacjonistyczne i ksenofobiczne, to jednak umożliwia nie tylko skuteczne przetrwanie w sytuacji przynależności do obcego językowo i przynajmniej częściowo kulturowo państwa, ale także pozwala skutecznie działać dla rozwoju własnej tożsamości, przekazywania jej kolejnym pokoleniom i utrwalania poprzez powszechnie rozpoznawalne symbole. W tym przypadku jako mniejszość narodowa i językowa mieszkańcy Wysp Alandzkich podlegają także ochronie stosownie do międzynarodowego i europejskiego systemu ochrony praw mniejszości, w szczególności będącego efektem prac ONZ i jej wyspecjalizowanych agend oraz Rady Europy i KBWE/OBWE. Jednak w duchu wspomnianego art. 22 Karty Praw Podstawowych wydaje się, że szczególną wartością w dzisiejszym świecie jest jego wieloaspektowa różnorodność. Jej zachowanie powinno być istotnym celem nie tylko dla zainteresowanych zbiorowości, ale również dla poszczególnych państw, szczególnie w sytuacji, gdy koncepcja Europy regionów wydaje się słabsza od koncepcji Europy narodów, z samej swej istoty promującej unifikację wewnątrz jak najbardziej jednorodnych państw.

60 S. Sagan, V. Serzhanowa, Konstytucja Finlandii, Rzeszów 2003, s. 70, 76 i 92.

61 Art. 22 Karty Praw Podstawowych, [w:] Dziennik Urzędowy Unii Europejskiej z 14 grudnia 2007, C 303. 


\section{Summary}

The author argues that the inhabitants of the Aland Islands exhibit a separate island identity. $\mathrm{He}$ describes the specific historical, geographical, social, political and legal situation of this region on the basis of the elements that constitute the local/regional symbolic universum. He points out that as a result of decades-long manifestations of a sense of separateness and of struggle to preserve and maintain this separateness, a regional culture has come into being, unique and specific to these Islands only. He claims that, based on this regional culture, a distinct ethnic identity has been constructed, that manifests itself as a strong collective WE, a sense that the inhabitants identify with the category "Aland Islander," yet without establishing a national identity, and with no aspirations for an independent sovereign state.

Keywords: the Aland Islands, Alander identity, regional culture 